OPEN ACCESS

Edited by:

Luis Cardona,

University of Barcelona, Spain

Reviewed by:

Guang Yang,

Nanjing Normal University, China

Silvina Botta,

Federal University of Rio Grande,

Brazil

*Correspondence:

Kerri J. Smith

smithkerrij@gmail.com

Specialty section:

This article was submitted to

Marine Conservation

and Sustainability,

a section of the journa

Frontiers in Marine Science

Received: 22 January 2020

Accepted: 05 May 2020

Published: 03 June 2020

Citation:

Smith KJ, Sparks JP, Timmons ZL and Peterson MJ (2020) Cetacean Skeletons Demonstrate Ecologically

Relevant Variation in Intraskeletal

Stable Isotopic Values.

Front. Mar. Sci. 7:388.

doi: 10.3389/fmars.2020.00388

\section{Cetacean Skeletons Demonstrate Ecologically Relevant Variation in Intraskeletal Stable Isotopic Values}

\author{
Kerri J. Smith ${ }^{*}$, Jed P. Sparks², Zena L. Timmons ${ }^{3}$ and Markus J. Peterson ${ }^{1}$
}

${ }^{1}$ Department of Biological Sciences, The University of Texas at El Paso, El Paso, TX, United States, ${ }^{2}$ Department of Ecology and Evolutionary Biology, Cornell University, Ithaca, NY, United States, ${ }^{3}$ Department of Natural Sciences, National Museums Scotland, Edinburgh, United Kingdom

Conservation science requires quickly acquiring information and taking action in order to protect species at risk of extinction. Stable isotope measurements are one way to rapidly gather data regarding species' foraging ecology and habitat use, and passively collected samples limit additional stress to at-risk species. For these samples to be useful, however, we must know how representative they are of the stable isotope ratios of the entire organism. Bone tissue, often stored in museum collections or research centers, may be the most readily available tissue from rare, endangered, or extinct vertebrates, but using bone requires practitioners to understand intraskeletal stable isotope variation. We sampled the same eight skeletal elements from 72 cetacean skeletons from 14 species to evaluate intraskeletal variation in carbon and nitrogen isotope values. We found considerably more variation than anticipated. Carbon intraskeletal ranges varied from 0.4 to $7.6 \%$, with $84.7 \%(n=61)$ of skeletons having a range $>1 \%$, and $55.5 \%$ $(n=40)$ exhibiting a range $>2 \%$. Similarly, nitrogen intraskeletal ranges varied from 0.4 to $5.2 \%$, with $59.7 \%(n=43)$ of skeletons exhibiting a range $>1 \%$, and $15.3 \%$ $(n=11)$ with a range $>2 \%$. There were differences in which bones contributed most to intraskeletal variation; however, we advise against using humeri and mandibles as these bones presented the most consistent trends in deviation from the intraskeletal means for both isotopes. The large intraskeletal variation we observed is likely due to changes in foraging behavior or habitat use being reflected differently in bone isotope ratios due to differences in bone turnover rates. We suggest that for cetaceans, intraskeletal carbon isotope ranges $>1 \%$ and nitrogen ranges $>2 \%$ are ecologically relevant, and that using different bones from animals of the same population may produce false positive differences in foraging behavior or habitat within the population if intraskeletal variation is not considered. Future studies should use the same bones from each animal and conduct species-specific analyses of intraskeletal variation, if possible, when using specimens of opportunity. Failure to consider this variation could lead to erroneous conclusions regarding a species range or key habitats, jeopardizing conservation efforts.

Keywords: bone, carbon, cetacean, conservation, intraskeletal variation, museum collections, nitrogen, stable isotopes 


\section{INTRODUCTION}

Conservation science is a crisis discipline because conservation action typically must be taken for species at risk of extinction before practitioners are confident in the sufficiency of their data (Soulé, 1985). One fundamental difficulty in wildlife conservation is rapidly understanding how species interact with, and utilize, their habitat (Aberg et al., 2000; Cristescu and Boyce, 2013). A variety of tools and research methods have been developed and employed to gain insight into habitat use. Typically, these methods require directly interacting with the animal in some manner, such as radio telemetry, capture or sedation to collect biological samples, or long-term observation; all of which can alter animal behavior (Brigham, 1989; Pietz et al., 1993; Guthery and Lusk, 2004; Brooks et al., 2008; Rachlow et al., 2014). Less invasive methods, such as camera traps and drones, still may alter animal behavior, as many animals identify the device in their habitat and interact with it (Meek et al., 2014, 2016; MuleroPazmany et al., 2017). Methods with no animal interactions, such as shore-based marine mammal observational studies, require thousands of observer hours, can be implemented over only limited spatial areas, are restricted in insight regarding surfacebased activities, and are susceptible to observer error (Rugh et al., 1990; Aragones et al., 1997).

Stable isotope analysis (SIA) is an innovative technique for investigating wildlife habitat use, such as providing insight into foraging behavior, niche segregation, individual-level resource utilization, and diet shifts (Hobson, 1999; West et al., 2006; Newsome et al., 2007). Studies incorporating SIA can employ a variety of tissue types, each providing unique temporal snapshots of ecological or dietary conditions reflecting the timeframe when the tissue was generated. Although many SIA studies use actively collected samples that require direct human - animal interaction, such as biopsy plugs or blood samples, one of the most powerful aspects of this technique is the ability to gain insight from passively collected samples, such as molted feathers or fur (McKechnie, 2004; Thompson et al., 2005). Feathers, for example, often incorporate the isotopic value of the water and food resources in the region where they are grown, and are excellent samples for identifying migratory or breeding grounds without requiring human - bird interaction (Chamberlain et al., 1997; Hobson et al., 2001; Guillemain et al., 2019). Thus, SIA of specimens of opportunity provides a powerful monitoring system that minimizes invasive activities, limits impacts on animal behavior, and can be rapidly completed. Opportunistically collected samples provide a valuable alternative to capturing or harassing wildlife, but present new challenges. For rare or difficult to locate animals, small sample size or less than ideal samples can complicate analyses (Ben-David and Flaherty, 2012; Hopkins and Ferguson, 2012). If researchers are attempting to gain insight into longer-term behavior from passively collected samples, such as feathers, bone remains from archeological sites, or more recent skeletal remains, they must determine if the sample evaluated accurately reflects the tissue's value for the animal as a whole.

In rare, endangered, or extinct vertebrate species, bone is often the only tissue available for SIA, and is routinely stored in museum and research collections. Despite the ubiquitous availability of bone tissue from vertebrates, comparatively few studies have focused on bone SIA (Vander Zanden et al., 2015), and only a small subset of these studies has examined isotopic variation among different bones from the same organism (Table 1). Bone tissue is slow to grow and regenerate, thus incorporating and reflecting diet isotopic signatures at a slower rate than other tissues (Newsome et al., 2007; Vander Zanden et al., 2015). Controlled feeding studies have been completed that examine bone isotopic values, many with the purpose of coupling isotopic values in bone with soft tissues (Ben-David et al., 1997; Hong et al., 2000; Phillips and Eldridge, 2006). However, these studies only examined matching bones, or the same bones in each study organism. Bone tissue is replaced and repaired at different rates depending on the bone's function, density, and size (Kohn and Cerling, 2002; Lafage-Proust et al., 2015). Due to these differing turnover rates in bone, different bones sampled from the same animal may have different isotopic values. In the case of rare or extinct species, it may be impossible to acquire complete skeletons, compelling researchers to compare isotopic values from different bones among conspecifics. These non-matching bones may suggest different diets, water sources, or other environmental parameters, not because individuals in a population were utilizing different resources, but because the bones reflect dietary or habitat shifts at different rates. Failure to consider isotopic variation among different bones of conspecific individuals may result in erroneous conclusions regarding environmental conditions and dietary habits.

In this study, we investigated intraskeletal stable isotope variation of $\delta^{13} \mathrm{C}$ and $\delta^{15} \mathrm{~N}$ in 14 cetacean species using skeletons from the National Museums Scotland osteological collection. Cetaceans are a quintessential example of the challenges conservation scientists face: studying cetaceans in situ is often invasive, requiring locating the animal, following it, and interacting with it in some way (Dawson et al., 2008; Ballance, 2009). These processes are time consuming and have numerous logistical challenges beyond required permitting. Cetacean skeletons, however, have been collected and housed in museum collections for hundreds of years, providing a large specimen-of-opportunity cache for researchers. By sampling multiple bones from the same skeleton, we can establish an understanding regarding how representative a given bone is of the entire skeleton, thus increasing the power of skeleton-based SIA studies, and providing a valuable contribution to passive habitat use studies.

\section{MATERIALS AND METHODS}

To test for intraskeletal isotopic variation, we sampled the same 8 bone locations from 72 cetacean specimens (14 species) housed in the National Museums Scotland osteological collection (Table 2 and Supplementary Table S1). In order to consistently sample the same location for each bone among individuals and species, we compared bone size and selected the same proportional sampling site. We selected these specimens because they were complete or near-complete skeletons, were well represented in the collection so small-scale destructive sampling 
TABLE 1 | Summary of data from previous studies that investigated intraskeletal $\delta^{13} \mathrm{C}$ and $\delta^{15} \mathrm{~N}$ isotopic variation relevant to our research.

\begin{tabular}{|c|c|c|c|c|c|}
\hline \multirow[t]{2}{*}{ References } & \multirow[t]{2}{*}{ Species } & \multirow[t]{2}{*}{ Sample locations } & \multirow[t]{2}{*}{$\begin{array}{l}\text { Number of } \\
\text { individuals }\end{array}$} & \multicolumn{2}{|c|}{$\begin{array}{l}\text { Avg. Intraskeletal } \\
\text { Range }(\%)\end{array}$} \\
\hline & & & & $\delta^{13} \mathrm{C}$ & $\delta^{15} \mathrm{~N}$ \\
\hline Deniro and Schoeniger, 1983 & Mink (unknown species) & Femur and humerus & 15 & 0.6 & 0.7 \\
\hline Deniro and Schoeniger, 1983 & Rabbit (unknown species) & $\begin{array}{l}\text { Femur, humerus, mandible, radius, scapula, distal } \\
\text { tibia, ulna }\end{array}$ & 3 & 0.3 & 0.3 \\
\hline $\begin{array}{l}\text { Riofrío-Lazo and } \\
\text { Aurioles-Gamboa, } 2013\end{array}$ & Mirounga angustirostris & Mandible, tooth, maxilla & 14 & 1.8 & 1.1 \\
\hline $\begin{array}{l}\text { Riofrío-Lazo and } \\
\text { Aurioles-Gamboa, } 2013\end{array}$ & Mirounga angustirostris & Mandible and maxilla & 17 & 0.8 & 0.5 \\
\hline Olsen et al., 2014 & Homo sapiens & Rib, fibula, metacarpal & 6 & 0.6 & 1.6 \\
\hline Webb et al., 2016 & Sus domesticus & Rib and femur & 48 & NA & 0.3 \\
\hline Cheung et al., 2017 & Homo sapiens & Femur and ulna & 1 & 1.8 & 0.3 \\
\hline Clark et al., 2017 & Odobenus rosmarus divergens & Cranium and mandible & 11 & 0.1 & 0.3 \\
\hline Clark et al., 2017 & Pusa hispida & $\begin{array}{l}\text { Calcaneus, mandible, femur, humerus, innominate, } \\
\text { phalanx, rib, scapula, metatarsal, vertebra }\end{array}$ & 1 & 0.9 & 1.2 \\
\hline Clark et al., 2017 & Phoca sp. & $\begin{array}{l}\text { Cranium, femur, humerus, innominate, phalanx, rib, } \\
\text { scapula, metatarsal, vertebra }\end{array}$ & 1 & 0.5 & 1.1 \\
\hline Clark et al., 2017 & Enhydra lutris & $\begin{array}{l}\text { Mandible, femur, humerus, innominate, rib, scapula, } \\
\text { metatarsal, vertebra }\end{array}$ & 1 & 1.2 & 0.7 \\
\hline Fahy et al., 2017 & Homo sapiens & $\begin{array}{l}\text { Femur, tibia, rib, radius, occipital, metacarpal, } \\
\text { humerus, thoracic vertebrae, pelvis, clavicle }\end{array}$ & 10 & 0.9 & 1.6 \\
\hline Bas et al., 2019 & Otaria byronia & Atlas, humerus, basioccipital & 14 & 0.8 & 1.3 \\
\hline
\end{tabular}

TABLE 2 | Number of individual animals sampled per species for each skeletal sampling location.

\begin{tabular}{|c|c|c|c|c|c|c|c|c|}
\hline \multirow[b]{2}{*}{ Species } & \multicolumn{8}{|c|}{ Skeletal sample location } \\
\hline & $\begin{array}{l}\text { Occipital } \\
\text { condyle }\end{array}$ & $\begin{array}{l}\text { Mandibular } \\
\text { ramus }\end{array}$ & $\begin{array}{c}\text { Thoracic } \\
\text { vertebral body }\end{array}$ & $\begin{array}{l}\text { Thoracic vertebral } \\
\text { spinous process }\end{array}$ & Proximal rib & Distal rib & Scapula & $\begin{array}{c}\text { Humeral } \\
\text { head }\end{array}$ \\
\hline Balaenoptera acutorostrata & 3 & 3 & 3 & 3 & 3 & 3 & $2^{*}$ & 3 \\
\hline Delphinus delphis & 5 & 5 & 5 & 5 & 5 & 5 & 5 & 5 \\
\hline Globicephala melas & 4 & 4 & 4 & 4 & 4 & 4 & 4 & 4 \\
\hline Kogia breviceps & 3 & 3 & 3 & 3 & 3 & 3 & 3 & 3 \\
\hline Lagenorhynchus acutus & 5 & 5 & 5 & 5 & 5 & 5 & 5 & 5 \\
\hline Lagenorhynchus albirostris & 5 & 5 & 5 & 5 & 5 & 5 & 5 & 5 \\
\hline Mesoplodon bidens & 10 & 10 & 10 & 10 & 10 & 10 & 10 & 10 \\
\hline Orcinus orca & 4 & 4 & 4 & 4 & 4 & 4 & 4 & 4 \\
\hline
\end{tabular}

We sampled the same locations by bone among individuals to reduce the effects of natural bone variability, and samples contained a mixture of cortical and trabecular bone. *One Balaenoptera acutorostrata skeleton was without scapulae and one Tursiops truncatus skeleton was without mandibles.

would not hinder future studies and encompassed the breadth of physiological and ecological variation in cetaceans. We aimed to limit our sampling to adult $(n=49)$ or subadult
( $n=11)$ specimens, but due to the limited number of specimens that contained all sampling locations we included 12 juvenile specimens in order to increase sample size. 
We used a battery powered handheld drill to remove $1 \mathrm{~g}$ of bone tissue and subsampled $200 \mathrm{mg}$ for collagen extraction. Our extraction protocol was adapted from Ambrose (1990) and Jorkov et al. (2007). We ground subsamples with mortar and pestle and performed lipid extractions in a 2:1 chloroform:methanol solution three times for $30 \mathrm{~min}$ each; if the supernatant was not clear after three washes, additional washes were carried out as needed. The mineral component was removed using a $30 \mathrm{~min} 0.5 \mathrm{M} \mathrm{HCl}$ bath followed by 3 deionized water rinses, and a $30 \min 0.1 \mathrm{M} \mathrm{NaOH}$ bath followed by 3 deionized water rinses. Previous studies demonstrated that bone tissue lipid extraction and acidification demineralization does not significantly alter $\delta^{15} \mathrm{~N}$ values (Tomaszewicz et al., 2015; Tatsch et al., 2016). We added $7 \mathrm{ml}$ of $\mathrm{pH} 3$ water to each sample and incubated at $80^{\circ} \mathrm{C}$ for $24 \mathrm{~h}$. The supernatant was collected and freeze-dried, resulting in purified collagen. Between 0.85 and $1.15 \mathrm{mg}$ of collagen was loaded in $3 \times 5 \mathrm{~mm}$ tin capsules and submitted for $\mathrm{C}$ and $\mathrm{N}$ stable isotope analysis.

Stable isotope analysis was completed at the Cornell Isotope Laboratory at Cornell University using a Thermo Delta V isotope mass spectrometer interfaced with a NC2500 elemental analyzer (ThermoFisher Scientific, Waltham, MA United States 02451). We calibrated our results using 2 primary reference scales: Vienna Pee Dee Belemnite for $\delta^{13} \mathrm{C}$, and Atmospheric Air for $\delta^{15} \mathrm{~N}$. To ensure accuracy and precision, we analyzed an in-house standard ( $\delta^{13} \mathrm{C}:-20.16 \pm 0.03 \% 0$ and $\delta^{15} \mathrm{~N}: 6.35 \pm 0.05 \%$ ) between every 10 samples. As an additional measure of extraction method and analysis accuracy and repeatability, we randomly selected 2 bones, subsampled 4 additional $200 \mathrm{mg}$ samples each, and followed the methods described above to extract collagen and analyze for stable isotope ratios $\left(\delta^{13} \mathrm{C}\right.$ : $-14.93 \pm 0.02 \%$ and $\delta^{15} \mathrm{~N}: 10.98 \pm 0.08 \% ; \delta^{13} \mathrm{C}:-13.79 \pm 0.05 \% 0$ and $\delta^{15} \mathrm{~N}$ : $11.55 \pm 0.06 \%$ ). We also evaluated collagen sample composition (percent carbon, percent nitrogen, and $\mathrm{C} / \mathrm{N}$ ratio) and collagen percent yield to monitor sample quality.

We employed descriptive statistics to explore intraskeletal variation among bone sampling locations for both $\delta^{13} \mathrm{C}$ and $\delta^{15} \mathrm{~N}$. Because we are not making comparisons among animals, we did not have to consider the Suess effect, which is longterm incorporation of isotopically light carbon into the marine ecosystem due to fossil fuel use (Keeling, 1979). Analyses were performed using R (R Core Team, 2018) with RStudio (RStudio Team, 2016).

\section{RESULTS}

We found a high degree of variation in the isotopic values among different bones taken from the same animal. For example, internal skeletal ranges for $\delta^{13} \mathrm{C}$ varied from 0.4 to $7.6 \%$, with $84.7 \%(n=61)$ of skeletons having a range $>1 \%$, and $55.5 \%$ $(n=40)$ exhibiting a range $>2 \%$ (Figure 1). Similarly, skeletal ranges for $\delta^{15} \mathrm{~N}$ varied from 0.4 to $5.2 \%$, with $59.7 \%(n=43)$ of skeletons exhibiting a range $>1 \%$, and $15.3 \%(n=11)$ with a range $>2 \%$. For all skeletons, and for both isotopes, at least one bone was $\geq 1$ SD from the skeletal mean, and in most skeletons multiple bones were $\geq 1$ SD from the mean. For $\delta^{13} \mathrm{C}$, the number of skeletons with $1,2,3$, and 4 bones $\geq 1$ SD from the mean was $23,31,14$, and 4 , respectively. For $\delta^{15} \mathrm{~N}$, the number of skeletons with $1,2,3$, and 4 bones $\geq 1$ SD from the mean was $10,41,17$, and 4 , respectively. In a subset of skeletons $\left(n=31\right.$ for $\delta^{13} \mathrm{C} ; n=17$ for $\left.\delta^{15} \mathrm{~N}\right), 1$ bone was $\geq 2$ SD from the skeletal mean and one bottlenose dolphin (Tursiops truncatus) skeleton had 4 bones $\geq 2$ SD from the mean for $\delta^{15} \mathrm{~N}$.

There were no consistent trends regarding which specific bones within an individual animal differed in isotopic values from the skeletal mean across specimens. However, the proximal rib sampling location demonstrated the lowest levels of deviation, with 6 specimens $(8.3 \%) \geq 1$ SD from intraskeletal mean $\delta^{13} \mathrm{C}$ values, and 7 specimens $(9.7 \%) \geq 1 \mathrm{SD}$ from $\delta^{15} \mathrm{~N}$ intraskeletal mean values. For $\delta^{13} \mathrm{C}, 50.0 \%(n=36)$ of humeral heads were $\geq 1$ $\mathrm{SD}$ lower than the skeletal mean (no humeral heads were +1 SD). Mandibular rami $(40.3 \% ; n=29)$ and scapulae $(16.7 \%$; $n=12$ ) had the second and third highest rates of deviation from mean skeletal $\delta^{13} \mathrm{C}$, and all bone sample locations had at least one representative with $\geq 1 \mathrm{SD}$. We found $56.9 \%(n=41)$ of mandibular rami were $\geq 1 \mathrm{SD}$ from the skeletal $\delta^{15} \mathrm{~N}$ mean; specifically, of these $22.0 \%(n=9)$ were greater than the mean, whereas $78.0 \%(n=32)$ were less than the mean. Humeral heads $(30.0 \% ; n=28)$ and occipitals $(25.0 \% ; n=18)$ had the second and third highest rates of deviation from the skeletal $\delta^{15} \mathrm{~N}$ average, and all bones had at least one representative $\geq 1$ $\mathrm{SD}$ from the mean.

Mean collagen yield was $10.6 \%$, with a range of $1.8-37.5 \%$. This includes 37 samples with artificially low percent yield due to a freeze dryer malfunction resulting in partial loss of the sample or producing collagen that was challenging to recover from the vial, which prevented obtaining an accurate weight. Mean \%C and \%N were 29.56 and 10.19, respectively, with a mean $\mathrm{C} / \mathrm{N}$ ratio of 3.49 .

\section{DISCUSSION}

Intraskeletal isotopic variation has not been well investigated across a variety of taxa, and only one other study has considered this topic for cetacean skeletons (Vander Zanden et al., 2015; Bas et al., 2019). Studies of this type are challenging due to difficulty in locating large numbers of intact skeletons of the same species. As a result, previous studies typically had small sample sizes, low numbers of sampling locations, or a combination of both (Table 1). We addressed this deficiency by combining a large sample size from five cetacean families with many bone sampling locations per skeleton (Table 2). We documented much greater intraskeletal isotopic variation than has previously been reported (Figure 1 and Table 1), suggesting that if analyses were to be expanded to other taxa, similar results may be observed.

We identified some noteworthy patterns in stable isotope values that can be used to better inform the design of intraskeletal isotope studies in cetaceans. The proximal rib demonstrated the lowest rate of deviation from both $\delta^{13} \mathrm{C}$ and $\delta^{15} \mathrm{~N}$ intraskeletal means and may be the best bone from our sampling locations to use for comparative studies. The $\delta^{13} \mathrm{C}$ isotopic value of half of all humeral heads was $\geq 1$ SD from the skeletal mean, so we 

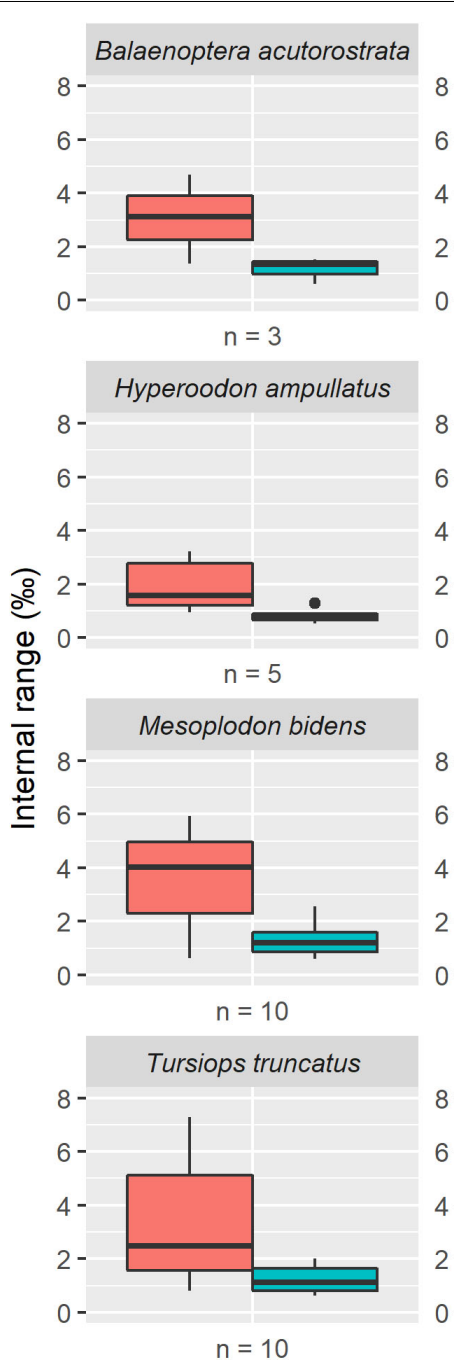
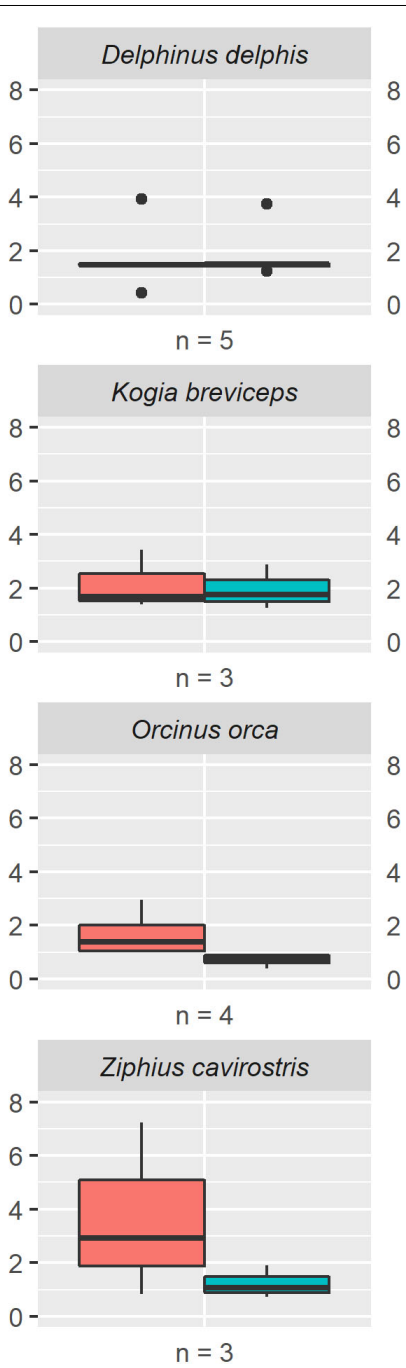
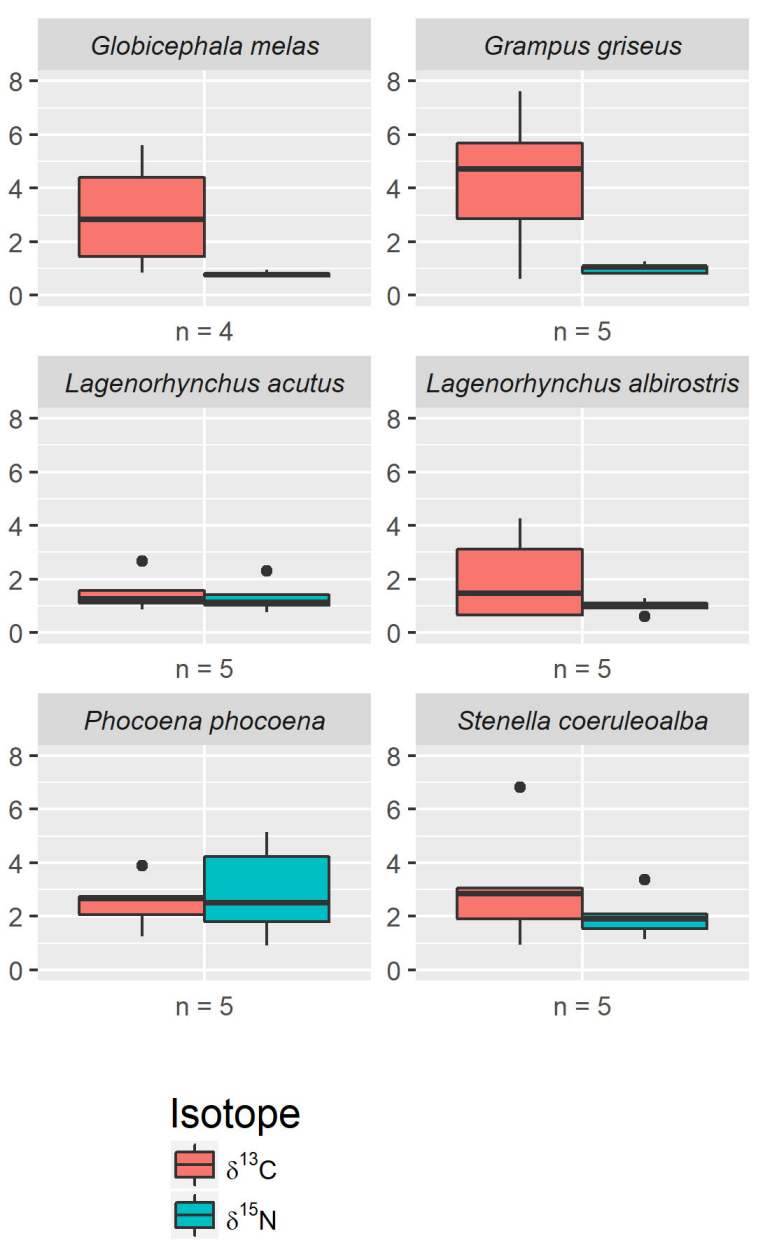

FIGURE 1 | Individual intraskeletal range for $\delta^{13} \mathrm{C}$ and $\delta^{15} \mathrm{~N}$, grouped by species ( $n=$ number of individual animals evaluated). Boxes present median and interquartile range and whiskers represent $95 \%$ confidence intervals.

advise against using this bone as representative of the skeleton as a whole. The mandibular ramus probably also should be avoided as we documented large, but inconsistent deviation from the skeletal mean for both isotopes. These two sampling locations represent two different bone types with different turnover rates. The humeral head is part of the humeral long bone and forms the shoulder joint with the scapula. However, cetacean skeletal and muscle anatomy studies have found that the humeral head is largely vestigial, and flipper movement is limited and related to maintaining balance and aiding in swimming speed (Cooper et al., 2007; Sanchez and Berta, 2010). As a result, this bone is under less ecophysiological pressure than other more mobile bones and joints. In contrast, the mandibular ramus is part of the dense mandibular irregular bone with a high degree of turnover and remodeling (Matsuura et al., 2014; Shadwick et al., 2017). In cetaceans, the mandible serves as the primary method of interacting with each other and the environment and is more susceptible to damage than other bones. These two bones represent distinct functions and turnover rates, and this may explain why they exhibit the greatest difference from the skeletal mean.

For 13 of 14 species in our study, $\delta^{13} \mathrm{C}$ was more variable than $\delta^{15} \mathrm{~N}$ (Figure 1). This trend is similar to cetacean intraskeletal isotopic variation reported by Bas et al. (2019), who compared $\delta^{13} \mathrm{C}$ and $\delta^{15} \mathrm{~N}$ isotope values among three sampling locations from 15 specimens (Table 1). They reported $\delta^{13} \mathrm{C}$ intraskeletal isotopic variation that fell within the lower range of variation in our study, and we suspect that had additional skeletal elements been compared, then variation found by our two studies may have been similar. Greater $\delta^{13} \mathrm{C}$ than $\delta^{15} \mathrm{~N}$ intraskeletal variation is also consistent with Riofrío-Lazo and Aurioles-Gamboa (2013), who found variation in northern elephant seal skeletons (Mirounga angustirostris) and for sea otter (Enhydra lutris) skeletons in Clark et al. (2017). Many human (Homo sapiens) archeological studies also reported this trend (Table 1), but these authors typically compared only two or three sampling locations. The study most 
similar in design to ours is Fahy et al. (2017); they compared $\delta^{13} \mathrm{C}$ and $\delta^{15} \mathrm{~N}$ isotope values between 10 sample locations in 10 humans. They found $\delta^{15} \mathrm{~N}$ intraskeletal variability was greater than $\delta^{13} \mathrm{C}$ variation; however, $\delta^{15} \mathrm{~N}$ variation was similar to values in our study. Only a few other studies examined intraskeletal variation in terrestrial vertebrates (Table 1). The differences observed between terrestrial and marine mammal studies may be due, in part, to different physiological pressures placed on bones in terrestrial versus aquatic and semiaquatic environments.

Newsome et al. (2010) documented that younger marine mammals exhibit higher bone turnover rates of carbon and nitrogen stable isotopes, possibly contributing to intraskeletal variation. We did not observe this pattern. In fact, adult animals demonstrated some of the highest levels of intraskeletal variation. For example, harbor porpoises (Phocoena phocoena) had relatively low levels of $\delta^{13} \mathrm{C}$ intraskeletal variation despite including one subadult individual, and the outlier animal was an adult (Figure 1). Atlantic white sided dolphins (Lagenorhynchus acutus) displayed generally lower levels of $\delta^{13} \mathrm{C}$ intraskeletal variation compared to white beaked dolphins (Lagenorhynchus albirostris), even though we sampled five adult specimens for each species. Amongst beaked whales, Sowerby's beaked whales (Mesoplodon bidens) displayed the greatest median $\delta^{13} \mathrm{C}$ intraskeletal variation despite including only adult animals, while both northern bottlenose whale (Hyperoodon ampullatus) and Cuvier's beaked whale (Ziphius cavirostris) samples included juvenile animals. No data on cetacean bone tissue turnover rates is available, but Newsome et al. (2006) estimated complete bone collagen turnover in yearling seals and sea lions at 8-10 months. If young cetaceans exhibit a similar pattern, then the moderate variation we observed in younger animals is logical because their bones are reflecting a shorter time span, and therefore less environmental variability than seen in older age classes. Thus, age class of the specimen does not seem to drive the variation we observed. Likewise, collection date and storage time of the specimens did not contribute to intraskeletal variation. All our specimens, with the exception of two, were collected since 1989, and the two older specimens demonstrated similar intraskeletal variation as modern specimens.

We were consistent in our sampling locations in each skeleton to reduce the introduction of additional variation due to natural differences throughout the bone. Each sample contained a mixture of mineralized cortical bone and spongy trabecular bone, and the inherent unequal ratios of these bone types at different sampling sites, and the differences in their turnover rates, may contribute to some of our observed intraskeletal variation (Manolagas, 2000; Clarke, 2008). However, if this was a major contributing factor, we would expect to see animals of the same species demonstrating similar trends in variation; instead, we saw considerable variation at the individual animal level. This suggests a combination of physiological and ecological factors driving isotopic variation. Carbon and nitrogen isotope ratios in a skeleton reflect habitat and diet, respectively (BenDavid and Flaherty, 2012). Organisms in controlled settings, such as in feeding studies or laboratories, show little isotopic variation when fed a consistent diet, even when considering bone turnover rates (Deniro and Schoeniger, 1983). Therefore, differences we observed in intraskeletal isotope ratios suggest differences in foraging behavior and individual-level resource utilization over time.

As animals switch habitats or consume different food sources, the rate isotopes from these sources are incorporated will vary among bones due to bone-specific turnover rates (Newsome et al., 2010). This combination of changing environmental isotope ratios and physiological mechanisms leads to ecologically relevant intraskeletal isotopic variation - that is, the isotopic values from different bones from the same individual could lead to different conclusions regarding an animal's life history if considered independently. This is especially important for studies forced to use non-matching bones for analyses. The amount of intraskeletal range that is ecologically relevant depends on the specific questions being asked, but we suggest that $\delta^{13} \mathrm{C}$ ranges $>1 \%$ and $\delta^{15} \mathrm{~N}$ ranges $>2 \%$ are ecologically significant for cetacean studies. Isoscape models built using specific prey resources of the species in this study do not yet exist, but we still can characterize how variation might affect researcher's conclusions by considering isoscapes already available. For example, an isoscape model built from jellyfish collected in waters around the British Isles demonstrates a 1-2\%o difference in $\delta^{13} \mathrm{C}$ values across the study area (Glew et al., 2019). Based on this, the $\delta^{13} \mathrm{C}$ variation we observed within the skeletons in our study would indicate different foraging locations along the United Kingdom shelf sea if the bone sample locations were considered independently. If a study is trying to identify important foraging or breeding habitats to make conservation recommendations and must make use of non-matching bones, a $1 \%$ difference may appear to suggest different regions of importance yet may simply represent differences among bones sampled from the same skeleton. Similarly, nitrogen isotope values in animals are enriched at rate of 3-4\% for each increase in trophic level (Post, 2002), yet we observed $\delta^{15} \mathrm{~N}$ intraskeletal range values up to $5.16 \%$.

Bone turnover rates and changes in habitat use or foraging behavior could explain much of the intraskeletal variation in carbon and nitrogen isotope ratios we observed, but there is still considerable unexplained variation. This could be due to physiological factors that are beyond the scope of our study, such as metabolic rates or bone disease/injury, both of which can alter bone growth patterns (Manolagas, 2000; Clarke, 2008; Olsen et al., 2014). We did not sample animals that had obvious signs of bone disease or injury remodeling, but there is little information regarding the individual life history of most specimens in our study. Thus, we do not know their movement patterns and habitat use, beyond general species information, or the specifics of their age or health. However, even amongst closely related species, such as Atlantic white sided dolphins and white beaked dolphins, which have overlapping habitats and grow to a similar size, we saw considerable differences in intraskeletal variation (Weinrich et al., 2001; Galatius and Kinze, 2016). For some species, such as bottlenose dolphins, specimens in our study may have come from different populations, with different foraging behavior and habitat use, further contributing to intraskeletal isotopic variation. Although we sampled a large breadth of cetacean species, we were limited to relatively small species 
sample sizes due to difficulty in acquiring complete skeletons. In two cases, we chose to include animals that were missing one of eight sampling locations to increase sample size for that species; if this study was repeated with much larger species sample sizes, further trends in variation may become apparent. Regardless, to truly understand factors driving individual and species variation, we would need data from hundreds of tagged animals of the same species - where all their life movement data is available to more systematically evaluate stable isotope variation for the species. Because this is not feasible for most cetacean studies, we instead must acknowledge that considerable variation exists within individual animals.

Specimens of opportunity are a critical resource for ecological studies, but they do present unique challenges that must be considered. Because opportunistically collected skeletons are often incomplete, necessitating comparisons between unmatched bones among animals, there is a need to understand intraskeletal isotopic variation. Our study demonstrates that substantial intraskeletal variation is present for the cetacean species we evaluated. Thence, we recommend that future studies using opportunistic bone tissue for stable isotope analysis conduct species-specific evaluations for intraskeletal variation. Failure to identify or consider this variation could have serious implications for studies that use bone isotope values to explore animal ecology. When the results of such studies are used to inform conservation action, it is imperative to consider that different bones from the same animals may suggest different habitats or resource use when none existed. Accounting for this intraskeletal variation in stable isotopes values produces more robust analyses and thus better-informed conservation management plans.

\section{DATA AVAILABILITY STATEMENT}

The datasets generated for this study are available on request to the corresponding author.

\section{REFERENCES}

Aberg, J., Jansson, G., Swenson, J. E., and Mikusinski, G. (2000). Difficulties in detecting habitat selection by animals in generally suitable areas. Wildlife Biol. 6, 89-99. doi: 10.2981/wlb.2000.004

Ambrose, S. H. (1990). Preparation and characterization of bone and tooth collagen for isotopic analysis. J. Archaeol. Sci. 17, 431-451. doi: 10.1016/0305-4403(90) 90007-r

Aragones, L. V., Jefferson, T. A., and Marsh, H. (1997). "Marine mammal survey techniques applicable in developing countries," in Asian Marine Biology, 14 Edn, eds B. D. Smith, and W. F. Perrin (Hong Kong: Hong Kong University Press), 15-39.

Ballance, L. T. (2009). “Cetacean ecology," in Encyclopedia of Marine Mammals, eds W. F. Perrin, B. Wursig, and J. G. M. Thewissen (Cambridge, MA: Academic Press).

Bas, M., Garcia, N. A., Crespo, E. A., and Cardona, L. (2019). Intraskeletal variability in stable isotope ratios of $\mathrm{C}$ and $\mathrm{N}$ among pinnipeds and cetaceans. Mar. Mamm. Sci. 36, 375-385. doi: 10.1111/mms. 12644

Ben-David, M., and Flaherty, E. A. (2012). Stable isotopes in mammalian research: a beginner's guide. J. Mammal. 93, 312-328. doi: 10.1644/11-mamm-s166.1

\section{AUTHOR CONTRIBUTIONS}

KS conceived the idea. KS, JS, and MP designed the methodology. KS and ZT coordinated the data collection. KS and MP analyzed the data. KS led the writing of the manuscript. All authors contributed critically to the drafts and gave final approval for publication.

\section{FUNDING}

This work was supported by the Inter-University Training for Continental Scale Ecology (ITCE) program sponsored by the National Science Foundation (EF-1241286).

\section{ACKNOWLEDGMENTS}

We thank National Museums Scotland, Edinburgh, for access to the cetacean specimens used in this study and Dr. Jeremy Herman of National Museums Scotland for his helpful guidance and support. Kim Sparks of the Cornell Isotope Laboratory provided invaluable support and guidance, and this manuscript greatly benefited from conversations with Clive N. Trueman. We also thank the editor (LC) and two reviewers for their helpful feedback and recommendations, which improved an earlier version of this manuscript.

\section{SUPPLEMENTARY MATERIAL}

The Supplementary Material for this article can be found online at: https://www.frontiersin.org/articles/10.3389/fmars. 2020.00388/full\#supplementary-material

Ben-David, M., Flynn, R. W., and Schell, D. M. (1997). Annual and seasonal changes in diets of martens: evidence from stable isotope analysis. Oecologia 111, 280-291. doi: 10.1007/s004420050236

Brigham, R. M. (1989). Effects of radio transmitters on the foraging behavior of barn swallows. Wilson Bull. 101, 505-506.

Brooks, C., Bonyongo, C., and Harris, S. (2008). Effects of global positioning system collar weight on zebra behavior and location error. J. Wildlife Manag. 72, 527-534. doi: 10.2193/2007-061

Chamberlain, C. P., Blum, J. D., Holmes, R. T., Feng, X. H., Sherry, T. W., and Graves, G. R. (1997). The use of isotope tracers for identifying populations of migratory birds. Oecologia 109, 132-141. doi: 10.1007/s004420050067

Cheung, C., Jing, Z. C., Tang, J. G., Weston, D. A., and Richards, M. P. (2017). Diets, social roles, and geographical origins of sacrificial victims at the royal cemetery at Yinxu, Shang China: new evidence from stable carbon, nitrogen, and sulfur isotope analysis. J. Anthropol. Archaeol. 48, 28-45. doi: 10.1016/j.jaa.2017. 05.006

Clark, C. T., Horstmann, L., and Misarti, N. (2017). Quantifying variability in stable carbon and nitrogen isotope ratios within the skeletons of marine mammals of the suborder Caniformia. J. Archaeol. Sci. Rep. 15, 393-400. doi: 10.1016/j. jasrep.2017.09.007

Clarke, B. (2008). Normal bone anatomy and physiology. Clin. J. Am. Soc. Nephrol. 3, S131-S139. 
Cooper, L. N., Dawson, S. D., Reidenberg, J. S., and Berta, A. (2007). Neuromuscular anatomy and evolution of the cetacean forelimb. Anatom. Rec. 290, 1121-1137. doi: 10.1002/ar.20571

Cristescu, B., and Boyce, M. S. (2013). Focusing ecological research for conservation. AMBIO 42, 805-815. doi: 10.1007/s13280-013-0410-x

Dawson, S., Wade, P., Slooten, E., and Barlow, J. (2008). Design and field methods for sighting surveys of cetaceans in coastal and riverine habitats. Mamm. Rev. 38, 19-49. doi: 10.1111/j.1365-2907.2008.00119.x

Deniro, M. J., and Schoeniger, M. J. (1983). Stable carbon and nitrogen isotope ratios of bone-collagen - variations within individuals, between sexes, and within populations raised on monotonous diets. J. Archaeol. Sci. 10, 199-203. doi: 10.1016/0305-4403(83)90002-x

Fahy, G. E., Deter, C., Pitfield, R., Miszkiewicz, J. J., and Mahoney, P. (2017). Bone deep: Variation in stable isotope ratios and histomorphometric measurements of bone remodelling within adult humans. J. Archaeol. Sci. 87, 10-16. doi: 10.1016/j.jas.2017.09.009

Galatius, A., and Kinze, C. C. (2016). Lagenorhynchus albirostris (Cetacea: Delphinidae). Mamm. Spec. 48, 35-47. doi: 10.1093/mspecies/sew003

Glew, K. S. J., Graham, L. J., Mcgill, R. A. R., and Trueman, C. N. (2019). Spatial models of carbon, nitrogen and sulphur stable isotope distributions (isoscapes) across a shelf sea: An INLA approach. Methods Ecol. Evol. 10, 518-531. doi: 10.1111/2041-210x.13138

Guillemain, M., Bacon, L., Kardynal, K. J., Olivier, A., Podhrazsky, M., Musil, P., et al. (2019). Geographic origin of migratory birds based on stable isotope analysis: the case of the greylag goose (Anser anser) wintering in Camargue, southern France. Eur. J. Wildlife Res. 65:67.

Guthery, F. S., and Lusk, J. J. (2004). Radiotelemetry studies: are we radiohandicapping northern bobwhites? Wildlife Soc. Bull. 32, 194-201. doi: 10. 2193/0091-7648(2004)32[194:rsawrn]2.0.co;2

Hobson, K. A. (1999). Tracing origins and migration of wildlife using stable isotopes: a review. Oecologia 120, 314-326. doi: 10.1007/s004420050865

Hobson, K. A., Mcfarland, K. P., Wassenaar, L. I., Rimmer, C. C., and Goetz, J. E. (2001). Linking breeding and wintering grounds of Bicknell's thrushes using stable isotope analyses of feathers. Auk 118, 16-23. doi: 10.1093/auk/ 118.1.16

Hong, J., Hipp, J. A., Mulkern, R. V., Jaramillo, D., and Snyder, B. D. (2000). Magnetic resonance imaging measurements of bone density and cross-sectional geometry. Calcified Tissue Int. 66, 74-78. doi: 10.1007/s002230050015

Hopkins, J. B., and Ferguson, J. M. (2012). Estimating the diets of animals using stable isotopes and a comprehensive bayesian mixing model. PLoS One 7:e28478. doi: 10.1371/journal.pone.0028478

Jorkov, M. L. S., Heinemeier, J., and Lynnerup, N. (2009). The petrous bone-a new sampling site for identifying early dietary patterns in stable isotopic studies. Am. J. Phys. Anthropol. 138, 199-209. doi: 10.1002/ajpa. 20919

Jorkov, M. L. S., Heinerneier, J., and Lynnerup, N. (2007). Evaluating bone collagen extraction methods for stable isotope analysis in dietary studies. J. Archaeol. Sci. 34, 1824-1829. doi: 10.1016/j.jas.2006.12.020

Keeling, C. D. (1979). The Suess effect: 13Carbon-14Carbon interrelations. Environ. Int. 2, 229-300. doi: 10.1016/0160-4120(79)90005-9

Kohn, M. J., and Cerling, T. E. (2002). "Stable isotope compositions of biological apatite," in Phosphates: Geochemical, Geobiological, and Materials Importance, eds M. J. Kohn, J. Rakovan, and J. M. Hughes (Chantilly: Mineralogical Society of America), 455-488. doi: 10.1515/9781501509636-015

Lafage-Proust, M. H., Roche, B., Langer, M., Cleret, D., Vanden Bossche, A., Olivier, T., et al. (2015). Assessment of bone vascularization and its role in bone remodeling. Bonekey Rep. 4:662

Manolagas, S. C. (2000). Birth and death of bone cells: Basic regulatory mechanisms and implications for the pathogenesis and treatment of osteoporosis. Endocrine Rev. 21, 115-137. doi: 10.1210/er.21.2.115

Matsuura, T., Tokutomi, K., Sasaki, M., Katafuchi, M., Mizumachi, E., and Sato, H. (2014). Distinct characteristics of mandibular bone collagen relative to long bone collagen: relevance to clinical dentistry. Biomed. Res. Int. 2014:769414.

McKechnie, A. E. (2004). Stable isotopes: powerful new tools for animal ecologists. S. Afr. J. Sci. 100, 131-134.

Meek, P., Ballard, G., Fleming, P., and Falzon, G. (2016). Are we getting the full picture? Animal responses to camera traps and implications for predator studies. Ecol. Evol. 6, 3216-3225. doi: 10.1002/ece3.2111
Meek, P. D., Ballard, G. A., Fleming, P. J. S., Schaefer, M., Williams, W., and Falzon, G. (2014). Camera traps can be heard and seen by animals. PLoS One 9:e110832. doi: 10.1371/journal.pone.0110832

Mulero-Pazmany, M., Jenni-Eiermann, S., Strebel, N., Sattler, T., Negro, J. J., and Tablado, Z. (2017). Unmanned aircraft systems as a new source of disturbance for wildlife: A systematic review. PLoS One 12:e178448. doi: 10.1371/journal. pone. 0178448

Newsome, S. D., Clementz, M. T., and Koch, P. L. (2010). Using stable isotope biogeochemistry to study marine mammal ecology. Mar. Mamm. Sci. 26, 509-572.

Newsome, S. D., Del Rio, C. M., Bearhop, S., and Phillips, D. L. (2007). A niche for isotopic ecology. Front. Ecol. Environ. 5, 429-436. doi: 10.1890/060150.1

Newsome, S. D., Koch, P. L., Etnier, M. A., and Aurioles-Gamboa, D. (2006). Using carbon and nitrogen isotope values to investigate maternal strategies in northeast Pacific otariids. Mar. Mamm. Sci. 22, 556-572. doi: 10.1111/j.17487692.2006.00043.x

Olsen, K. C., White, C. D., Longstaffe, F. J., Von Heyking, K., Mcglynn, G., Grupe, G., et al. (2014). Intraskeletal isotopic compositions $(\delta 13 c, \delta 15 n)$ of bone collagen: nonpathological and pathological variation. Am. J. Phys. Anthropol. 153, 598-604. doi: 10.1002/ajpa.22459

Phillips, D. L., and Eldridge, P. M. (2006). Estimating the timing of diet shifts using stable isotopes. Oecologia 147, 195-203. doi: 10.1007/s00442-005-0292-0

Pietz, P. J., Krapu, G. L., Greenwood, R. J., and Lokemoen, J. T. (1993). Effects of harness transmitters on behavior and reproduction of wild mallards. J. Wildlife Manag. 57, 696-703.

Post, D. M. (2002). Using stable isotopes to estimate trophic position: Models, methods, and assumptions. Ecology 83, 703-718. doi: 10.1890/0012-9658(2002) 083[0703:usitet]2.0.co;2

R Core Team (2018). R: A Language and Environment for Statistical Computing. Vienna: R Foundation for Statistical Computing.

Rachlow, J. L., Peter, R. M., Shipley, L. A., and Johnson, T. R. (2014). Sub-lethal effects of capture and collaring on wildlife: Experimental and field evidence. Wildlife Soc. Bull. 38, 458-465. doi: 10.1002/wsb.444

Riofrío-Lazo, M., and Aurioles-Gamboa, D. (2013). Timing of isotopic integration in marine mammal skull: Comparative study between calcified tissues. Rapid Commun. Mass Spectr. RCM 27, 1076-1082. doi: 10.1002/rcm. 6556

RStudio Team (2016). RStudio: Integrated Development for R. 1.0. Boston, MA: RStudio Inc.

Rugh, D. J., Ferrero, R. C., and Dahlheim, M. E. (1990). Inter-observer count discrepancies in a shore-based census of gray whales (Eschrichtius robustus). Mar. Mamm. Sci. 6, 109-120. doi: 10.1111/j.1748-7692.1990.tb 00233.x

Sanchez, J. A., and Berta, A. (2010). Comparative anatomy and evolution of the odontocete forelimb. Mar. Mamm. Sci. 26, 140-160. doi: 10.1111/j.1748-7692. 2009.00311.x

Shadwick, R. E., Goldbogen, J. A., Pyenson, N. D., and Whale, J. C. A. (2017). Structure and function in the lunge feeding apparatus: mechanical properties of the fin whale mandible. Anatom. Rec. 300, 1953-1962. doi: 10.1002/ar.23647

Soulé, M. E. (1985). What is Conservation Biology? A new synthetic discipline addresses the dynamics and problems of perturbed species, communities, and ecosystems. BioScience 35, 727-734.

Tatsch, A. C. C., Secchi, E. R., and Botta, S. (2016). Effects of acidification, lipid removal and mathematical normalization on carbon and nitrogen stable isotope compositions in beaked whale (Ziphiidae) bone. Rapid Commun. Mass Spectr. 30, 460-466. doi: 10.1002/rcm.7457

Thompson, D. R., Bury, S. J., Hobson, K. A., Wassenaar, L. I., and Shannon, J. P. (2005). Stable isotopes in ecological studies. Oecologia 144, 517-519.

Tomaszewicz, C. N. T., Seminoff, J. A., Ramirez, M. D., and Kurle, C. M. (2015). Effects of demineralization on the stable isotope analysis of bone samples. Rapid Commun. Mass Spectr. 29, 1879-1888. doi: 10.1002/rcm. 7295

Vander Zanden, M. J., Clayton, M. K., Moody, E. K., Solomon, C. T., and Weidel, B. C. (2015). Stable isotope turnover and half-life in animal tissues: a literature synthesis. PLoS One 10:e0116182. doi: 10.1371/journal.pone.011 6182

Webb, E. C., Stewart, A., Miller, B., Tarlton, J., and Evershed, R. P. (2016). Age effects and the influence of varying proportions of terrestrial and marine dietary 
protein on the stable nitrogen-isotope compositions of pig bone collagen and soft tissues from a controlled feeding experiment. Sci. Technol. Archaeol. Res. 2, 54-66. doi: 10.1080/20548923.2015.1133121

Weinrich, M. T., Belt, C. R., and Morin, D. (2001). Behavior and ecology of the Atlantic white-sided dolphin (Lagenorhynchus acutus) in coastal New England waters. Mar. Mamm. Sci. 17, 231-248. doi: 10.1111/j.1748-7692.2001.tb 01268.x

West, J. B., Bowen, G. J., Cerling, T. E., and Ehleringer, J. R. (2006). Stable isotopes as one of nature's ecological recorders. Trends Ecol. Evol. 21, 408-414. doi: $10.1016 /$ j.tree.2006.04.002
Conflict of Interest: The authors declare that the research was conducted in the absence of any commercial or financial relationships that could be construed as a potential conflict of interest.

Copyright (c) 2020 Smith, Sparks, Timmons and Peterson. This is an open-access article distributed under the terms of the Creative Commons Attribution License (CC BY). The use, distribution or reproduction in other forums is permitted, provided the original author(s) and the copyright owner(s) are credited and that the original publication in this journal is cited, in accordance with accepted academic practice. No use, distribution or reproduction is permitted which does not comply with these terms. 